\title{
MANAGING CORRUPTION IN SOUTH AFRICA: THE ETHICAL RESPONSIBILITY OF CHURCHES
}

\author{
JM Vorster \\ Faculty of Theology \\ North-West University
}

\begin{abstract}
The South African society continues to stagger under an immense wave of corruption in both the private and the public sectors. Corruption is the misuse of public office or a position of authority for private, material or social gain at the expense of other people. The aim of this investigation is to discuss the phenomenon from a moral point of view and to suggest moral directives and ways that can assist the Christian churches to address corruption from a Christian ethical angle of approach. The church lives by its testimony and by its ministry. Based on this vocation the churches have the responsibility to engage in the struggle against corruption by raising ethical awareness and constantly reminding society at large of the plight of the poor. Pointing to Christ as the model of human conduct, the churches should enhance the deeper meaning of self-interest, honesty, fairness, responsibility, compassion, love and accountability. The development of an attitude of servanthood and stewardship according to the attitude of Christ is of specific importance in the process of raising ethical awareness. These values are much needed in a culture of corruption driven by self-interest and greed. And last but not least, the churches must always call for social justice and never refrain from reminding the prosperity-driven South African society that as long as the current large-scale poverty prevails, corruption will be difficult to curtail.
\end{abstract}

Key Words: Corruption, Greed, Self-Interest, Ethical Awareness, Stewardship, Servanthood

\section{Introduction}

In spite of the emphasis in the South African Constitution (Government of South Africa, 1996:107) on a high standard of professional ethics in Public Administration, the South African society continues to stagger under an immense wave of corruption in both the private and the public sectors. Corruption is the misuse of public office or a position of authority for private material or social gain at the expense of other people. It represents a departure from ethics, morality, tradition, law and civic virtue (Dassah, 2008:38; Mafunisa, 2007:261). Corruption manifests itself as bribery, embezzlement, fraud, extortion, abuse of power, nepotism, conflict of interests, insider trading or abuse of privileged information, and favouritism (Webb, 2009:9). However, corruption should not only be defined as those actions that are illegal in terms of the laws of a country, but also those deeds that are regarded by the public as immoral. An act regarded as immoral and illegal is an obvious case of corruption (Anderson, 2008:198). However, a definition of corruption should not be used interchangeably with terms such as inefficiency and ineffectiveness (Webb, 2005:153). Corruption takes place as an intentional, illegal and immoral act of behaviour with the purpose of gaining some kind of advantage. 
Corruption research has developed considerably in the last fifteen years (Anderson, 2008:193). New possibilities for empirical macro-oriented research came into being, and this resulted in the development of indices that enable studies on corruption, its causes and effects. The indices of corruption worldwide as provided by Transparency International annually, is especially helpful to these empirical studies. According to the 2009 report of Transparency International (2009:2), South Africa was rated $55^{\text {th }}$ out of 180 countries on the Corruptions Perceptions Index (CPI) with a count of 4.7 on a scale of $1-10$. The 2010 report indicates that the situation improved slightly when South Africa moved to the $54^{\text {th }}$ position with a count of 5 (Transparency International, 2010:2). Corruption is costing South Africans billions of Rands a year. At the well-known Shaik trial an anti-corruption expert testified that about $5 \%$ of the country's gross domestic product is lost to corruption annually (Dassah, 2008:53). ${ }^{1}$

Corruption has enormous negative consequences for the development of an orderly and peaceful society. While South Africa is in the process of nation-building, the culture of corruption endangers the social fibre of society and inhibits moral renewal. Not only does corruption promote a general lack of trust in institutions and leadership, but it stimulates a perpetual culture of corruption that invades all spheres of life. Moreover, empirical work confirmed that irrespective of the objective characteristics of a country's political and social system, subjective evaluations of corruption do themselves appear to influence investment decisions, growth and the political behaviour of citizens (Treisman, 2000:400).

A close scrutiny of indexes of Transparency International indicates that several factors can be associated with lower perceived corruption, and these are worthwhile to mention in order to assess the South African situation. These are:

- Countries with Protestant traditions have more developed economies and higher quality governments than Catholic and Muslim countries because of less interventionist policies. Evidence suggests that causation runs from economic development to lower corruption, as well as from corruption to slower development (Treisman, 2000:401).

- Countries with a history of British rule can be generally rated as 'less corrupt' due to the common law legal system associated with superior government (La Porta, et al. 1999:240).

- Ethnolinguistically homogeneous countries have better governments than heterogeneous countries, and common law countries have better governments than French civil law and socialist law countries (La Porta et al. 1999:258).

- Federal states are, according to many indices, more 'corrupt' than unitary ones. Treisman (2000:401) ascribes this fact to the competition between autonomous levels of governments to extract bribes.

- Less corruption is significant in a country with a long period of exposure to democracy, irrespective of its current democratic status.

- Corruption is higher in countries where domestic firms are sheltered from international competition by natural or policy induced barriers to trade. Economies dominated by a smaller number of firms or where antitrust regulations are not effective in preventing anticompetitive practices, tend to have more corruption (Ades \& Di Tella. 1999:992). Openness to trade may reduce corruption.

\footnotetext{
The Shaik trial in South Africa was of public importance because the accused person, S Shaik was the personal financial advisor of the current State President The court found this person guilty of fraud and sentenced him to prison. In passing judgement, the judge described the relationship between this person and the State President as "corrupt."
} 
These findings by empirical studies over a wide spectrum of disciplines, suggest why fighting corruption in many countries is so difficult and time consuming. Quick and superficial solutions are usually not successful and expectations to curb the wave of corruption in the short term may be too high. Measuring corruption in South Africa within the framework of these findings leads to contradictory end results. On the one hand the country has a long and influential Protestant tradition, was exposed to British colonial rule with a common law legal system and has moved a long way away from interventionist policies by the government. These factors should have inhibited corruption, according to the findings of the empirical studies referred to. On the other hand, the country was also exposed to factors that enhance corruption such as being a federal state, a culturally and ethnic heterogeneous society and a very short exposure to true democracy. Corruption can therefore be expected. However, the fact of the matter is that corruption in South Africa is unacceptably high and it inhibits the process of nation-building and moral renewal.

The aim of this investigation is to discuss the phenomenon from a moral point of view and to suggest moral directives and ways that can assist the churches to address corruption from a Christian ethical angle of approach. The concept 'church' will be used in this investigation to refer to the local congregation, in other words, to the teaching and ministry of believers and their vocation in society. Dassah (2008:38) reminds us that ethical behaviour and professionalism are hallmarks of good governance. With this statement as the angle of approach, the central theoretical argument of this article is that Christian ethics provide moral directives that can be utilised by churches to contribute to the development of a milieu where corruption can be trimmed down and where ethical leaders can be developed. The research will not engage in yet another empirical study, but will refer to the results of various valuable and credible empirical studies that have been conducted in the recent past. Firstly, the causes of corruption in South Africa will be analysed. Secondly, the underlying attitudes of corrupt officials will be investigated and thirdly ethical solutions applicable to a corrupt environment will be proposed, accompanied by suggestions regarding the way in which the churches could utilise these.

\section{The Causes of Corruption}

The theory of Treisman (2000:402) regarding the causes of corruption is worthwhile to consider in order to establish whether this theory will also apply to the current South African situation. He contends that officials misuse public funds when they are satisfied that there is a low risk of being caught and punished. The probability of getting nabbed depends in part on the effectiveness of the country's legal system. It also depends on the legal culture and the presence of effective anti-corruption mechanisms. In this respect Treisman (2000:403) agrees with the viewpoint of La Porta et al., which holds that those countries with a common law system such as Britain and its former colonies have a better chance to expose corruption due to its almost obsessive focus on the procedural aspects of the law. Stiglitz (2002:185) proves the argument by referring to the corruption in the Czech Republic as an example of what could happen if the law and legal culture are not defended. A second cause of corruption, according to Treisman, is closed undemocratic political systems, because the risk of exposure is lower in these societies. He also stresses the role of religion. Where religions become 'state-religions,' the risk of nepotism and corruption is higher because these religions do not play the important monitoring role they should. His hypotheses are then that countries with an effective legal system and legal culture and countries with a Protestant tradition will have a lower incidence of corruption. 
This theory of Treisman can be questioned when it is applied to the South African situation. The common law system did not prevent corruption during the Apartheid era and did not reduce corruption after the transition to a full democracy and the institution of a Liberal Democracy with a modern constitution. South Africa has indeed an open and democratic system, but still corrupt officials do not fear exposure and punishment. Moreover, Protestantism in South Africa, especially the influential Reformed tradition, played a minor role in monitoring the governments of both the pre-1994 and the post-1994 dispensations. Here Protestantism did not inhibit the corruption pre-1994 or the contemporary levels of corruption. On the other hand the theory is correct in the sense that a robust legal culture and uncompromised religions can reduce corruption.

Other possible causes for corruption in South Africa should be investigated. In this respect the unique situation in the country must be taken into consideration. The country is in the process of a transition after three centuries of colonial rule and the period of Apartheid. The new constitution opens up processes that aim to promote economic equality and accessibility of all to the economic resources of the country. The policy of Affirmative Action was planned and instituted to address the legacy of Apartheid, namely the economic gap between white and black and the absence of blacks in all spheres of the labour market. This programme is founded on the Promotion of Equality and Prevention of Unfair Discrimination Act of 2000 (Act 4 of 2000), which required every minister and level of government to implement measures aimed at achieving equality (Terreblanche, 2000:47). Another programme is the policy of the government to restructure the economy in such a way that the participation of blacks in entrepreneurial and highly skilled jobs, as well as their entitlement to property, would increase (Terreblanche, 2000:437). Moreover, many measures to promote social security were put in place such as large housing programmes, social grants and bursaries and loans for technical and academic training. These drastic and far-reaching programmes entailed an enormous flow of capital in the circles of the central government, regional governments and local municipalities.

These programmes are necessary for the promotion of human dignity and equality, but also have a negative side. In 2004 R2 billion was lost in social grant scams and the state may have lost up to R10 billion in the first decade of majority rule (Dassah, 2008:53). It seems that the legal systems were not effective in controlling the huge flow of capital, and this shortcoming and deficient legal culture contributed to corruption (see Mafunisa, 2007:261). In spite of various court cases where corrupt officials were exposed and sentenced, the wave of corruption spread to all spheres of government. Bribery in the case of the allocations of tenders by government officials for the development of housing projects and the much-needed development of the infra-structure to create employment opportunities, is the order of the day. Hence the expression 'tenderpreneurs' to describe people who enriched themselves by gaining contracts in an illegal way or as a result of nepotism, political loyalties and pro-struggle credentials.

The affirmative action programme has noble intentions and is a necessary component in the process of nation-building and moral renewal. However, the execution of the programme also fuelled corruption. Terreblanche (2002:447) argues that the programme was perhaps driven too vigorously. The pool of black people to replace white officials in the public sector was too small. He says: "Consequently, many positions in the higher echelons of the bureaucracy - at all three administrative levels - were filled with black people who did not have the experience, professionalism, commitment, or culture of service needed to be productive and loyal civil servants. To complicate matters further, many of the new appointees are - like their white predecessors - indulging in nepotism, corruption and 
careerism" (Terreblanche, 2002:448). He is of the opinion that it will be extremely difficult to purge the bureaucracy of incompetence so that a culture of service can take root (see also Faull, 2007:1). Terreblanche made these comments in 2002, but now, ten years later, they are still valid and illustrative of the present state of affairs (see also Van der Merwe, 2006:33).

According to the Country Corruption Assessment Report (CCAR) of the United Nations (United Nations. 2003:1), fraud, theft and bribery are amongst the most common forms of corruption in the public sector in South Africa. This corruption is more common in some sectors such as the South African Police Service (SAPS), and the departments of transport, housing, public works, education and health. It is more prevalent in the provinces of the Eastern Cape and KwaZulu-Natal, and is generally in the moderate to high category (Van der Merwe, 2006:35). The report assumes that the corruption in the public sector has its source in the private sector. Public sector officials are corruptible and they actively create or supply opportunities for corrupt transactions. According to Van der Merwe (2006:36) the causes in these cases have been identified as personal greed, poverty, poor checks and balances, poor salaries, a lack of ethics, and the decay of moral societal values. Inefficient management is also a cause of corruption, and the affirmative action programme has been ranked as the fourth most significant cause of corruption by anti-corruption agents.

Of particular concern are the high levels of corruption in the South African Police Service (SAPS). This phenomenon was researched, amongst others, by Faull (2007) and Basdeo (2010). While some researchers contend that it is only the actions of a small number of individuals that tarnish the reputation of an organisation (the rotten apple theory), Faull (2007:7) referred to the fact that it is widely accepted within the organisation that SAPS corruption is widespread, but seldom acted upon. Basdeo (2010:385) states that policing and corruption in South Africa goes hand in hand, and the fact that the two are inextricably linked is a grave matter as the police organisation is the prime agency of the state for law enforcement and social control. In spite of the fact that various mechanisms were developed since 1996 to curb the corruption in this public sector, police corruption is still pervasive. Basdeo (2010:386) refers to a survey of the Institute for Security Studies which indicated in 2003 that the SAPS was found to be the second most corrupt public sector organisation after traffic officials.

Various causes for police corruption have been identified. As early as 1982 Johnston (1982:82) blamed corruption in the SAPS on the type of person who becomes a police officer. The occupation tends to attract the lower class individuals who do not have the skills or means to equip themselves for future middle class positions. As they develop the cynical, authoritarian police personality, accepting graft seems to be an all-too-easy way of achieving financial security. Related to this phenomenon is the view that the wide discretion police officials enjoy makes them candidates for corruption (Basdeo (2010:392). Moreover, Faull (2007:7) refers to the low managerial and public visibility of front line members, the stress of the job, peer group secrecy and the engagement with criminality on a daily basis as causes for corruption. Both Basdeo (2010:393) and Faull (2007:8) deal with the possibility that low remuneration in the SAPS is a direct cause for corruption, and they conclude that this perception is not true because great improvements have been made in the salary levels of police officials, and it compares well with the remuneration of nurses and teachers. Increases in police salaries to eliminate police corruption do not necessarily solve the problem of corruption. The vigorous implementation of affirmative action without the necessary training as mentioned by Terreblanche $(2002: 447)$ is also a cause of corruption 
because untrained police officials were appointed and promoted at the cost of skilled, trained professionals.

All surveys done in this respect identify the same causes for corruption in the public sector namely greed, lack of moral values, insufficient mechanisms to deal with corruption, a lacking legal culture, unskilled and poorly trained officials, lack of control over the flow of capital in the processes of social security, poverty and the absence of an adequate moral fibre in the society at large. However, very few officials will admit that they act immorally on purpose, and they will present certain values to justify their actions. Usually these actions will be justified by calling on a certain underlying attitude that is then presented to gloss over their deeds. Therefore a discussion of these projected attitudes is necessary when dealing with the problem of corruption. Taking the causes of corruption into account, the next section will investigate the attitudes presented by corrupt officials and promoters of the culture of corruption in the South African public sectors.

\section{Underlying Attitudes}

Dealing with corruption entails amongst other things that the underlying attitudes should be addressed. These attitudes will be evaluated in the light of a Christian ethical perspective.

The misuse of public funds for the purpose of self-enrichment is generally rooted in a negative form of self-interest, which entices officials to greediness. Self-interest per se is not immoral and can be seen as an acceptable moral principle in business and in the administration of human rights. In the ethics of human rights every person can be seen as an end in itself, no person is a mere instrument to the convenience or welfare of any other human being. Whosoever denies this principle can also logically deny people's equal claims of access to the bounty of the earth (Ryan, 1996:113). Moreover, the argument of Childs (1995:14) about self-worth in the field of labour can also be applied to the concept of self-interest in general. Every person lives with a sense of being 'somebody' and a fear of being a 'nobody'. Self-interest as a goal in any form of negotiating a deal is not necessarily negative and immoral. Any person has the right to act in his or her own interest in order to gain benefits or profits.

The problem with self-interest arises when it is based on an immoral motivation or purpose. When self-interest roots in the misuse of public funds it becomes theft, and when it leads to greediness and mere self-enrichment, it becomes selfishness. Moreover, when self-interest is pursued to the detriment of other people, it becomes a morally negative attitude. Self-interest therefore becomes immoral when it leads to the exploitation of others. Abuses of public funds for own gains are immoral and illegal. It is more so when it concerns the needy. Corrupt officials can become so obsessed with the 'self' that they totally disregard the interest of others, especially the people with no voice such as the poor, the elderly, the sick, the disadvantaged and people in need. Their actions can develop into a violent way of behaving because greed is a form of violence (Premawardhana, 2011:226). This exploitation is a prominent characteristic of the wave of corruption in South Africa today, because funds allocated for the improvement of the lives of the poorest of the poor are misused and stolen. It is incomprehensible that some public officials in South Africa, many of whom experienced the sufferings of Apartheid and poverty first hand, become corrupt when they deal with programmes directed at promoting the interest of the people who suffered with them in the previous dispensation.

Low wages and unemployment are among the causes of corruption, especially in developing countries (Dassah, 2008:43; Webb, 2009:8). Such a predicament entices 
officials to an attitude of "taking from the system what is rightfully mine". A general cause of corruption in the public sector can thus be the attitude of 'self-remuneration'. With such an attitude underpaid individuals develop the perception that they were, or still are, taken advantage of, even exploited, and that they do not receive the recognition they deserve. They then steal from the department with the argument that they just take what they in any case deserve. They defend their own corrupt actions with the argument that they have moral justification to enrich themselves at the expense of the exploitative system. The end justifies the means, and with such a moral theory they explain their actions away. Another form of self-interest is nepotism, careerism and favouritism. Especially in African cultures strong attachments to the extended family and ethnic group, and expectations of sharing benefits lead many civil servants to engage in corrupt acts to meet their social obligations. The attitude of allegiance to one's family, ethnic or religious group or socio-economic identity is another socially-embedded factor that drives public officials to corrupt practices (Dassah, 2008:48).

Corrupt officials can also be driven in their actions by the idea that they serve a 'holy' purpose and that corruption can be justified when it serves this purpose. This 'purpose driven' attitude to corruption comes to the fore when officials appoint or promote certain individuals against the rules of the game because they are convinced that these appointees are in the best interest of the ideology of the government or of the policy of the department. Corrupt actions are thus also sanctified by the consequentialist moral theory, which entails that the end justifies the means (see Edwards, 2008:81). Other examples of this attitude of purpose driven corruption can be to misuse funds to benefit someone else who is in need. Hospitals are prone to this form of corruption where medical material is stolen to give treatment to patients who cannot afford treatment in a hospital or other medical facilities. The offenders will justify their actions with the argument that they serve a good and laudable cause.

A consequentialist approach may seem acceptable in these cases because the underlying attitude is perceived as morally good. "I take what I deserve" and "I steal to serve the needy or a bigger ideological purpose" are attitudes that have the ring of acceptable moral action in an emergency situation where the normal is not attainable. In the words of Douma (1992:126) such an attitude may be approved as a mendacium officiosum (a lie that renders a service). Ethics in an emergency situation may apply a consequentialist theory (see Vorster, 2004:105). However, this theory is questionable when the topic at hand is considered. In a normal situation these forms of corruption should not be tolerated because the end does not justify the means, but rather tarnishes it (Anan, 2002:2). The words of Gandhi (1994:354) are worthwhile to consider in this regard. He said: " 'Means are after all means'. I would say 'means are after all everything'. As the means so the end. There is no wall of separation between means and end. Indeed the Creator has given us control (and that too, very limited) over means, none over the end. Realisation of the goal is in exact proportion to that of the means. This is a proposition that admits no exception".

For churches to play a positive role in combating corruption in South Africa, a deeper understanding of these causes of corruption and the underlying attitudes of corrupt officials are necessary. The church is in essence a moral agent in society and does not deal with the legal structures necessary to control corruption. It should not interfere in the government's sphere of sovereignty. However, the church can and should deal with the moral issues at hand when the causes and attitudes of corruption are investigated. The church must act as the 'voice of the voiceless' when others remain silent. 


\section{The Role of the Church}

In various studies and surveys specific remedies for unethical conduct have been proposed, such as a free press, independent courts of law, and unscrupulous behaviour by political leaders, as well as government reform (Webb, 2009:7; Dassah, 2008:65; Sindane, 2007:218). The United Nations (2003:126) provided an adequate anti-corruption strategy for combating corruption in South Africa. This report proposes steps that can be taken by the government to address the problem of corruption. These steps should be supported by churches. However, the question remains: "What can be done by the church in civil society in the process of combating and preventing corruption"? It goes without saying that the church should support all legal measures taken by the authorities to prevent corruption and should fulfil the role of a 'watchdog' and a whistle blower in their monitoring role of public administration and the administration of justice. Although it is not the task of churches to interfere in the sphere of the authority of government, the churches have a public role to play. Christians and the church are called as public witnesses (Smit,2007:153; see also Koopman \& Smit, 2007:269). As the people of God's Kingdom, the main task of the church regarding social problems lies within the domain of ethics. I explained the ecclesiological model for the ministry of reconciliation in a socio-political context in a recent article (Vorster, 2010:429). ${ }^{2}$ The model I proposed can also be applied to the issue at hand. When dealing with the problem of corruption, churches, as the 'power station' of the kingdom of God, can apply three specific strategies to assist in combating this social problem in South Africa. I would like to focus on these practical guidelines which entail: Raising awareness of the problem, addressing the underlying attitude of self-interest, and calling for social justice.

\section{Raising Awareness of the Problem and its Effects}

In his study about ethics in the Public Sector, Edwards (2008:77) says that the 'ethical repair task' in the public sector must begin with as many individuals as possible making their consciences heard through every available form. Moreover, he argues that to instil an ethical culture in the public sector it is important that there should be a real paradigm shift from a neutral stance on ethical issues to a situation where ethical behaviour at all levels is practiced by management and staff and becomes a way of life. What Edwards says about management and staff can be extended to everyone in society. It is important that the whole community should develop an awareness of the extent of corruption. The causes, attitudes and negative impact of this phenomenon on people, peace and prosperity should be identified. Awareness is the first step in dealing with corruption (United Nations, 2003:88; Van Rooyen, 2008:400; Webb, 2005:162). In this respect churches have an important role.

\footnotetext{
The research article examines an ecclesiological model suitable for the promotion of socio-political reconciliation in the South African context from a Reformed theological and philosophical perspective. Its point of departure is that Reformational Theology is per definition a Public Theology, which is inter alia directed at the renewal of society, and that churches have a positive role to play in this regard. Firstly, the article investigates the historic contribution of the Kuyper ecclesiology and Dooyeweerd's perspective on social life and the Philosophy of the Idea of Law. Secondly, the article focuses on the biblical concept "Kingdom of God" and its implications for an ecclesiological model. Taking into account the contributions of these two lines of thought, the article concludes that the church should be seen as the "power station" of society. The church should equip believers to promote socio-political transformation in society. Moreover, the church should be actively engaged in socio-political transformation by preaching the reconciliation in Christ and its implications for society, and by being an example of reconciliation amidst a divided community by overcoming the divisions caused by racism, tribalism, sexism, xenophobia, homophobia and ethnocentrism in its own midst.
} 
The church is a community of moral discourse (Gustafson, 1988:53) or, in the words of Hauerwas (1983:42), 'a community of character' that does not have a social ethic, but is a social ethic. The church has, first of all the calling to be a 'prophet' who identifies the ills of society. Gustafson (1988:7) makes, with certain reservations, a case for rigorous prophetic discourse in the eyes of evil. But he also emphasises the value of moral discourse and policy discourse that is more than rearranging the deck chairs on a sinking Titanic (Gustafson, 1988:44).

Churches are deeply involved at the grassroots level of society and can be seen as moral 'opinion makers' in communities. The church functions amongst the rich, the poor and the poorest of the poor. Christians have a first-hand knowledge of the social ills of societies. They function in all spheres of life - in government, civil society and informal societal structures. The churches are in an excellent position to raise awareness of the problem of corruption and its negative effects on society. In a recent publication with the title: "Ethical leadership and the challenges of moral transformation", Dames and other scholars (Dames, 2009:1) discuss the quest for moral leadership in South Africa. In his article in this publication, Le Bruyns (2009:49) underlines the necessity of ethical leadership by religious traditions. In his view ethical leadership in this domain is capable of transforming institutions and envisions new possibilities for a more humane society and the foundation of 'common good life'. Such an involvement by Christians regarding the raising of awareness of corruption and its effects can bring about what Le Bruyns has in mind.

Of particular importance is the raising of ethical awareness (Webb, 2009:9; Dassah, 2008:56; Sindane, 2007:219). The empirical study conducted by the United Nations (2003:130) disclosed a serious lack of ethical awareness in South African corporations due to the following state of affairs:

- Ethics training is too brief to be effective and is not focused on important groups of employees, such as new entrants and managers;

- Some $27 \%$ of the respondents indicated that new employees are trained in the application of the organisation's code of ethics;

- Some 13\% said that new employees are taught ethical decision-making skills;

- Some $12 \%$ indicated that new employees are assisted in integrating ethics into their everyday activities; and

- Many organisations have not assigned a senior manager to handle the ethics responsibility.

Van Rooyen (2008:400) found that although ethics is generally acknowledged as an important factor in organisational activity, it does not achieve high-level priority status within the context of organisational decision-making strategic thrust (see also Magahy \& Pyman, 2010:58). Managers in key strategic positions do not attribute enough value to entrenching active ethics practice within their organisations. The report of the United Nations (2003:129) is relevant with the following judgment: It cannot be expected of public sector officials or others to be vigilant in combating corruption unless there is a commonly accepted set of ethics that serves as the ground rules. All sectors of society have a duty to ensure that children and adults alike know what is right and what is wrong. A national system of ethics must be clear on what constitutes corruption. An Ethical Framework is essential for social and economic development. It is common knowledge that corruption promotes the wrong developmental and investment choices. It encourages competition in bribery, rather than competition in quality and in the price of goods and services. It inhibits the development of a healthy marketplace and distorts economic and social development. Moreover, evidence shows that if corruption is not contained, it grows exponentially. As 
soon as a pattern of successful bribery is institutionalised, corrupt officials demand larger bribes, resulting in market inefficiency. These are all due to a low ethical awareness in society at large and within the sectors of public governance.

Churches are by definition moral agents. With their strong influence in all spheres of the South African society, churches can use their prophetic calling through preaching and teaching and the involvement of Christians in society to enhance the alertness that corruption is wrong and that behaviours such as greed, nepotism, careerism, favouritism and exploitation are morally untenable and socially destructive. On the foundation of these well-developed biblical moral standards, Christians can promote ethics in the public sector and develop a public sector ethos and educate people regarding corruption control buttressed by an application of sound ethics (Van der Merwe, 2002:41). In the execution of their calling in society to develop an anti-corruption moral ethos, they especially have to shed light on the role of the attitude of self-interest. This task will subsequently be addressed.

\section{Dealing with Self-interest}

The causes of corruption are rooted in certain attitudes (mind-sets, ways of thinking). As explained above, the attitude of self-interest and what it entails is very prominent in the culture of corruption. Churches have a tremendous influence on the formation of the attitudes of people and can thus play a highly important role in rectifying wrong attitudes that can have bearing on corruption. In the development of morality Van der Ven (1998:382) developed the idea of character formation as an essential aspect of moral education. In this respect churches can fulfil an important educational task by way of the formation of a moral sensitivity amongst believers for the detrimental effects of the pursuance of self-interest at all cost.

In this moral education the attitude of Christians should be addressed. Attitude is a very important concept in any ethical reflection. Ethics does not only focus on human conduct and the prescriptive norms for that conduct, but also on human attitudes and the prescriptive norms for change of attitudes. Ethical conduct flows from a specific attitude that is determined by a certain worldview. Attitude is also a very important concept in Christian anthropology due to the call upon Christians to mirror the attitude of Christ in their pursuit of rights and responsibility to fulfil their obligations. This angle of approach will be pursued in this investigation. A Christian view on attitude according to the biblical text of Philippians 2:4 was dealt with in a recent book (Vorster, 2007:17). The results of that research will be applied to the topic at hand.

Of particular importance is the evaluation of the attitude of self-interest from a Christian ethical perspective. Christian ethics has always been aware of the widespread human tendency of individuals to prefer their own interests to those of others. Humans tend to be biased toward members of their own groups, to steer away from outsiders and to rationalise self-serving behaviour through morality (Pope, 2007:267). Self-interest is a positive attitude in the pursuit of human dignity and human rights, but it should be balanced with an attitude of self-denial when the pursuit of the human dignity and human rights of others, especially the poor and marginalised, are concerned.

Christ had an attitude of recognition and promotion of public interest, and this should be imitated by his followers in society (Philippians 2:4-11). Broadly speaking, the expression: 'but made himself nothing' in this passage indicates that Christ became human (Ridderbos, 1971:77). But there is even more involved in this act of becoming human. The verb keno 
has the meaning of 'to make oneself available for' (Floor \& Viljoen, 2002:99). In other words, Christ became humane. But, he did not come to earth as king in the power and splendour of a glorified human nature. He came as an ordinary man (Muller, 1955:83). While recognising his indissoluble divine nature, he became human to be amongst humans, to suffer with and for them, and he associated himself with the sinners and the marginalised of society. One can imitate Christ in his humaneness, his solidarity with the needy and people in social distress. He can be imitated in his attitude of caring, love, sacrificing of his own interests and general compassion. Compassion is cum-patio, which means to 'feel with' (Fedler, 2006:178). As such his attitude must flow over to the attitude of Christians. This ethical principle, resulting from this part of the Christological hymn in Philippians 2, requires that Christians are called to 'agape', that is all inclusive love, which entails to be humane, compassionate and to make one available for people in their quest for comfort, justice, dignity and respect. This conclusion is strengthened by Christ's instruction to his disciples that they must wash each other's feet (John. 13:12-17). Self-interest must be tempered by the attitude of self-denial, especially when it comes to the interest of the poor and the marginalised.

The positive attitude of people in inter-personal relations should take the form of servanthood. In Christian anthropology the concept of servanthood is deeply embedded in the idea of the imitatio Christi (Phillippians 2:7). In a culture of corruption the promotion of servanthood is important. According to this passage in Phillippians, Christ took on the nature of a servant as a result of his abasement. The word used for servant is the same word used for a slave (doulos). As in the Hebrew Bible, the idea of slavery is used here to illustrate the relationship between God and His people. This imagery is also found in the texts of Romans 1:1 and 1 Peter 2:16. The slave was full-time in service of his owner and had limited freedom according the will of the owner. What is the deeper meaning of this image?

Firstly, one can contend that Christ became an example of the human being's relation to God. People should be servants of God with the limited moral freedom permitted by God. Every action should be an expression of this image of Christ. In the whole scope of ethical conduct people should be examples of the service Christ rendered to God. The service of God must not be narrowed down to worship. Christian life is more than worshipping in liturgical forms. This life entails a life in service of God by promoting truth, justice, fairness and love. The true servants of God are those willing to struggle for a good cause (Bonhoeffer, 1995:61). The ethical implications of Christ's act of servanthood are abundant. This act implies that human beings, as part of their servanthood, should imitate his truthfulness, love, and compassion in their struggle against unjust social structures, and in their promotion of peace and goodwill.

The churches should guide people to come to the conviction that self-interest has limits and that servanthood is the moral directive in inter-personal relations. The true servant will serve the community without the spirit of greed and self-enrichment. Churches as moral opinion makers should be potent advocates of compassion and true humaneness. It is these moral concepts that will make people realise that corruption in South Africa is to steal from the poorest of the poor, and that is not only illegal, but also one of the worst kinds of immorality. Flowing from the moral directive of humaneness is the responsibility of churches to call on the powers of the day and to society at large for social justice. 


\section{Calling for Social Justice}

Although corruption is a reality in all societies, the global surveys indicate clearly that corruption is higher and more destructive in developing countries and poor countries (Transparency International, 2010; Treisman, 2000:438). Where severe poverty prevails and officials with jobs are paid mediocre salaries, the possibility that they will be enticed into corruption is much higher than in affluent societies or even developing societies where the unemployment rate is low. A lowly paid official living amongst jobless people and in a poor extended family has no other choice than to provide for himself and his family by taking bribes, misusing funds and by exploiting the system (see Mafunisa, 2007:260 and Van der Merwe, 2006:32). Corruption with the attitude of 'self-remuneration' or a 'holy purpose' comes to the fore in these kinds of conditions. Dassah (2008:55\&58) indicates that even the best reform measures are bound to fail in the absence of good salaries as incentives. A good case can be made for paying people in public service handsomely. There is a direct relation between high-level administrators and low corruption.

The implementation of legal instruments to curb corruption is important and many such instruments exist in the South African public administration (Edwards, 2008:80). In addition to this, it is crucial to raise ethical awareness through moral agents. However, even the best instruments, programmes and education are bound to fail when a community is the victim of poverty and joblessness. The high and the low of corruption are directly linked to the socio-economic standing of a community. Therefore, social and economic development can be seen as the most important remedy for corruption, with the condition that the other instruments, programmes and education to curb corruption are also in place.

The imitation of Christ also means to cry out for justice to all people. In modern contextual theologies a clear case is made for churches to be the voice of the poor and to be the watchdog of governments and corporations when it comes to socio-economic justice. The church exists vicariously in the world, which is for the sake of the 'other', says De Gruchy (2002:94). The church should stand up for a caring economy that addresses the plight of the poor (Goudzwaard \& De Lange, 1995:72). In different situations this responsibility of the church may take different shapes. In the developed countries the role of the church could be to raise an ethical awareness regarding people's responsibility in a consumerist culture and the neo-liberal economic philosophy. However, in South Africa the church should also take the plight of the poor to heart by raising questions constantly and keeping the debate about the alleviation of poverty alive. A church that exists 'for the other' should raise issues in the public domain, such as:

- Are wages fair and sufficient for people to live a decent life?

- Is job creation the priority in the public and the private sectors?

- Is the extension and implementation of socio-economic rights one of the national priorities?

- Is the economic policy of the government of the day conducive for the alleviation of poverty?

- Are labour laws and practices fair?

Due to the Reformational principle of sovereignty in own sphere it is not the task of the churches to take over the responsibilities of other social spheres such as civil societies, trade unions, political parties or the government. However, they should be active as a watchdog, taking care of the plight of the poor and the marginalised and being the custodian of truth, honesty, fairness and compassion. In this way churches can be deeply 
involved in combating corruption because they are then dealing with the root causes of the problem.

\section{Conclusion}

All the surveys referred to in this investigation indicate how wide-ranging, far-reaching and destructive the current wave of corruption in South Africa is. As a complicated problem with many causes and many-sided manifestations it needs a multi-faceted answer. The answer that the churches can provide is but only one of these solutions. However, it is important due to the fact that the churches can, according to their primary vocation, penetrate to the centre of the problem, namely moral decay and poverty. The churches cannot promulgate laws and devise legal instruments. Those are the tasks of the government and corporations and people with expertise in the field of law and economics. The church lives by its testimony (Bright 1977:164) and by its ministry. On the foundation of this vocation the churches should enter the struggle against corruption, especially by raising ethical awareness and constantly reminding society at large of the plight of the poor. Pointing to Christ as the model of human conduct and attitude the churches should enhance the deeper meaning of honesty, fairness, responsibility, compassion, love and accountability. Of special value in this raising of ethical awareness is the development of the attitude of servanthood and stewardship according to the attitude of Christ. These values are much needed in a culture of corruption driven by self-interest and greed. And last but not least, the churches must never refrain from reminding the prosperity-driven part of the South African society that as long as the current large-scale poverty prevails, corruption will be difficult to curtail.

\section{BIBLIOGRAPHY}

Ades, A, Di Tella, R 1999. Rents, competition and corruption. The American Economic Review. 89(3)982-993.

Andersson, S 2008. Studying the risk of corruption in the least corrupt countries. Public Integrity. 10(3)193-214.

Basdeo, V 2010. The curse of corruption in the South African Police: A rot from within. South African Journal of Criminal Justice (23)3:385-400.

Bonhoeffer, D 1995. Ethics. London: Simon \& Schuster.

Bright, J 1977. The Kingdom of God. New York: Abingdon Press.

Childs, JM (jnr), 1995. Ethics in Business. Faith at work. Minneapolis: Fortress.

Dames, G 2009 (ed.). Ethical leadership and the challenges of moral transformation. Stellenbosch: SUN Press.

Dassah, MO 2008. Is there a hole in the bucket? Identifying drivers of public sector corruption, effects and instituting effective combative measures. Journal of Public Administration. 43(3.1):37-62.

De Gruchy, J.W. 2002. Reconciliation. Restoring justice. Minneapolis: Fortress.

Douma, J 1992. Verantwoord handelen. Kampen: Kok. 
Edwards, T 2008. The nuts and bolts of ethics, accountability and professionalism in the public sector: An ethical leadership perspective. Journal of Public Administration. 43(3.1):77-88.

Faull, A 2007. Corruption and the South African Police Force. Pretoria: Institute of Security Studies.

Fedler, KD 2006. Exploring Christian Ethics. Biblical Foundations for Morality, Louisville Westminster John Knox Press.

Floor, L \& Viljoen, FP 2002. Die Christus-himne in Fillippense: Soteriologies of Eties? In die Skriflig, 36(1):91-104.

Gandhi, M 1997. Young India, July, 17, 1924, In Ishay, MR, The Human Rights Reader. Major Political, Speeches, Essays and Documents from the Bible to the Present. London: Routledge p.350-357.

Goudzwaard, B \& De Lange, H 1995. Beyond poverty and affluence. Toward an economy of care. Grand Rapids: Eerdmans.

Government of South Africa 1996. The Constitution of the Republic of South Africa 1996. Pretoria: Government of South Africa.

Gustafson, JM 1998. Varieties of Moral Discourse. Prophetic, Narrative, Ethical, and Policy. Grand Rapids: Calvin College and Seminary.

Hauerwas, S 1981. A Community of Character. Towards a Constructive, Christian Social Ethic, London: Notre Dame,

Johnston M, 1982. Political corruption and public policy in America. Pacific Grove: Brooks/Cole.

Koopman, N \& Smit DJ, 2007. Public witness in the economic sphere? On human dignity as a theological perspective. In Hansen, L (ed). Christian in public. Aims, methodologies and issues in public theology. Beyers Naude Centre on Public Theology. Stellenbosch: Sun. 269-280.

La Porta, R, Lopez-de-Silantes, F, Shleifer, A, Vishny, RW1999. The quality of government. Journal of Law, Economics and Organization. 15(1):222-279.

Le Bruyns, C 2009. Ethical leadership in and through religious traditions. In Dames, G 2009. Ethical leadership and the challenges of moral transformation. Stellenbosch: SUM Press. 47-60.

Mafunisa, MJ 2007. Corruption and service delivery in the public services: The case of Limpopo Province. Journal of Public Administration 42(3):260-270.

Magahy, B \& Pyman, M 2010. Ethics and business conduct in defence establishments: An international review. Journal of Military Ethics. 9(1):57-76.

Muller, JJ 1955. The Epistle of Paul to the Philippians and to Philemon. Grand Rapids: Eerdmans.

Pope, SJ 2007. Human evolution and Christian Ethics. Cambridge: University Press.

Premawardhana S 2011. Greed as violence: Methodological challenges in interreligious dialogue on the ethics of the Global Financial Crisis. Journal of Religious Ethics. 39(2):223-245

Ridderbos, H 1971. Paulus, Ontwerp van zijn Theologie. Kampen: Kok. 
Ryan, JA 1996. Economic Justice. Selections from Distributive Justice and a Living Wage. Louisville: Westminster John Knox Press.

Sindane, AM 2007. Sustaining good governance: Is ethics and anti-corruption initiatives and agencies the answer? Journal of Public Administration. 42(5):212-221.

Smit DJ 2007. Essays in Public Theology. Collected essays 1. Stellenbosch: Sun Press.

Stiglitz, J 2002. Globalization and its discontents. London: Penguin.

Terreblanche, S 2000. A history of inequality in South Africa 1652-2002. Sandton: KMM Review Publishing Company.

Transparency International 2009. Corruptions Perceptions Index 2009. [Web] http://www.transparency.org/layout/set/print/policy_research/serveys/cpi/2009/ results (Date of Access 21 April 2010).

Transparency International 2010. Corruptions Perceptions Index 2010. [Web] http://www.transparency.org/layout/set/print/policy_research/serveys/cpi/2009/ results (Date of Access 27 April 2010).

Treisman, D 2000. The causes of corruption: a cross-national study. Journal of Public Economics. 76(2000) 399-457.

United Nations 2003. Country Corruption Assessment Report. The Government of the Republic of South Africa and the United Nations Office on Drugs and Crime. New York: United Nation's Office on Drugs and Crime.

Van der Merwe, A 2006. The nature and causes of corruption: The perceptions of KZN public service managers and anti-corruption agents. Journal of Public Administration. 41(1):32-46.

Van der Ven, JA 1998. Formation of the moral self. Studies in Practical Theology. Grand Rapids: Eerdmans.

Van Rooyen, EJ 2008. The leadership and ethics interface: Strengthening human resources and organisational capacity for development. Journal for Public Administration. 43(3.1):396-407.

Vorster, J.M. 2004. Ethical perspectives on human rights. Potchefstroom: Potchefstroom Theological Publications.

Vorster, JM 2007. Christian attitude in the South African Liberal Democracy. Potchefstroom, Potchefstroom Theological Publications.

Vorster, JM 2010. 'n Ekklesiologiese model vir die bediening van die versoening in ' $\mathrm{n}$ sosio-politieke konteks. In die Skriflig. 44(2):429-454.

Webb, W 2005. Applying the public service anti-corruption strategy in pursuit of accountable South African Public Administration. Journal of Public Administration. 40(2):151-165.

Webb, W 2009. Prevention is better than cure. Promoting public service integrity. $S A$ Crime Quarterly. 27(3):7-13. 